\title{
Local community perception of Joint Forest Management and it's implications for forest condition: the case of Dambwa Forest Reserve in Southern Zambia.
}

\author{
${ }^{1,5}$ Maxwell Phiri, ${ }^{2 *}$ Paxie W Chirwa, ${ }^{3}$ Scotney Watts and ${ }^{4}$ Stephen Syampungani \\ ${ }^{1}$ Forestry Department, Forestry Research Division, Kitwe, Zambia, \\ Email:mgphiri@yahoo.com \\ ${ }^{2}$ University of Pretoria, Lynwood Road, Faculty of Natural and Agricultural Sciences, \\ Pretoria 0002, South Africa, Email: paxie.chirwa@up.ac.za \\ ${ }^{3}$ Parliament of South Africa, Cape Town, South Africa, \\ Email: swatts@parliament.gov.za \\ ${ }^{4}$ Copperbelt University, School of Natural Resources, Kitwe, Zambia, Email: syampungani@,cbu.ac.zm \\ ${ }^{5}$ Department of Forest \& Wood Science, Stellenbosch University, Matieland 7602, South Africa \\ *Corresponding author email: paxie.chirwa@up.ac.za
}

The study conducted at Dambwa Forest Reserve in Livingstone, Zambia evaluated the perception of local people about joint management of the forest reserve in the area and if there had been improvements to the livelihoods of the community and the ecological condition of the forest following joint forest management. Generally, more people $(68 \%)$ participated in joint forestry management meetings than in forestry activities such as forest patrol and prescribed early burning and the size of the household significantly influenced the involvement of community members in JFM activities. The results also showed that the social status of the local community members played a significant role in their participation in JFM activities with the forest committee member group being the most involved (57-61\%). The perception of most members of the community was that there were neither monetary benefits derived from JFM nor any significant improvement in their livelihood following JFM. While there were high regeneration levels $(10,000$ saplings per ha) for all the species, among the selected commercial trees, only Pterocarpus angolensis, Baikiaea plurijuga and Colophospermum mopane had natural regeneration consisting of 118, 72 and 67 saplings per ha, respectively. Overall, $89 \%$ of the stems for the selected commercial species were less than $30 \mathrm{~cm} \mathrm{DBH}$; rendering them unsuitable for harvesting. It can be concluded that while the promotion of community involvement in forest protection and management contributes to regeneration of forest tree species, the communities did not perceive JFM as having improved their livelihood.

Keywords: community participation; forest resource; forest regeneration; forest condition; joint forest management

\section{Introduction}

In the past, forest management strategies were more concerned with conservation of forests and woodland at the expense of human benefits (Vandergeest, 1996). Therefore, state ownership of forests in which the people were kept out of the forest was a dominant feature of forest 
management programmes in most African countries (Raphael and Swai, 2009). However, the majority of rural households, particularly in Africa, derive a wide range of products for their subsistence from the rich and diverse vegetation type (Chirwa et al, 2008; Sethi and Khan, 2001). It is not possible therefore to have the forests for exclusive use by the state alone and deny forestadjacent communities access to the forests (Lise, 2000). The local communities, particularly poorer households, would continue to access and use the forest resource whenever available despite not having legal tenure rights to access the forest resources. In addition, the lack of local community participation in forest management has generally meant local communities have a negative attitude towards conservation efforts and the enforcement of conservation-related regulations (Obua et al. 1998). On the other hand, it has to be recognized that most forest reserves do allow local communities access for non-timber forest products.

The international pressure for sustainable natural resource management following the Earth Summit in Rio de Janeiro in Brazil in 1992 led to the recognition of the role of local communities in natural resource management and revision of policies in many countries (Jumbe and Angelsen, 2007; UNCED 2008). Drawing upon common pool resource theory, it is assumed that forests can be better managed when forest users are involved in making and adapting rules that include; appropriate management strategies; monitoring impacts; and resolving the conflicts that arise from the management of natural resources (Ostrom 1999). Participatory forest management (PFM) or joint forest management (JFM) therefore appears to be one of the solutions for reducing deforestation and alleviating poverty among the rural poor. 
JFM is a strategy meant to promote sustainable forest management by encouraging the management or co-management of forest and woodland resources by the communities living closest to them supported by a range of other stakeholders drawn from local governments, civil society and the private sector (Blomley and Ramadhani, 2005). Through JFM initiatives, communities are expected to manage their environment based on ecological principles, and benefit economically by becoming stewards of the forests and the lands that are close to them (World Bank, 2004). The practice of JFM in recent times has been accepted as the way for sustainable management of forest resources. It is well documented that JFM provides opportunities for local people to participate in forest conservation and management, thereby contributing to improved status of forests and the well-being of local communities (Wily, 2002). The approach is based on the concept of involving the local people whose daily lives are affected by the operation of a forest management system in the forest management (Wily, 2001; PFAP, 2005).

The Government of Zambia initiated a JFM arrangement to co-manage forest reserves with the involvement of forest-adjacent communities in line with the revised National Forestry Policy. This was expected to reduce management costs, have a positive impact on the quality of forest resources and improve the livelihoods of local communities over time (GRZ 1998; ZFAP 1998; Murali et al. 2003; PFAP 2005). The objectives of this study were therefore to (i) determine the perception of the local communities of joint forest management; (ii) identify factors that influence the community participation in co-managing the forest reserve; (iii) establish if there had been improvements to both the livelihoods of the community and the condition of the forest. 


\section{Methods and materials}

\section{Study site}

\section{Dambwa Joint Forest Management Area}

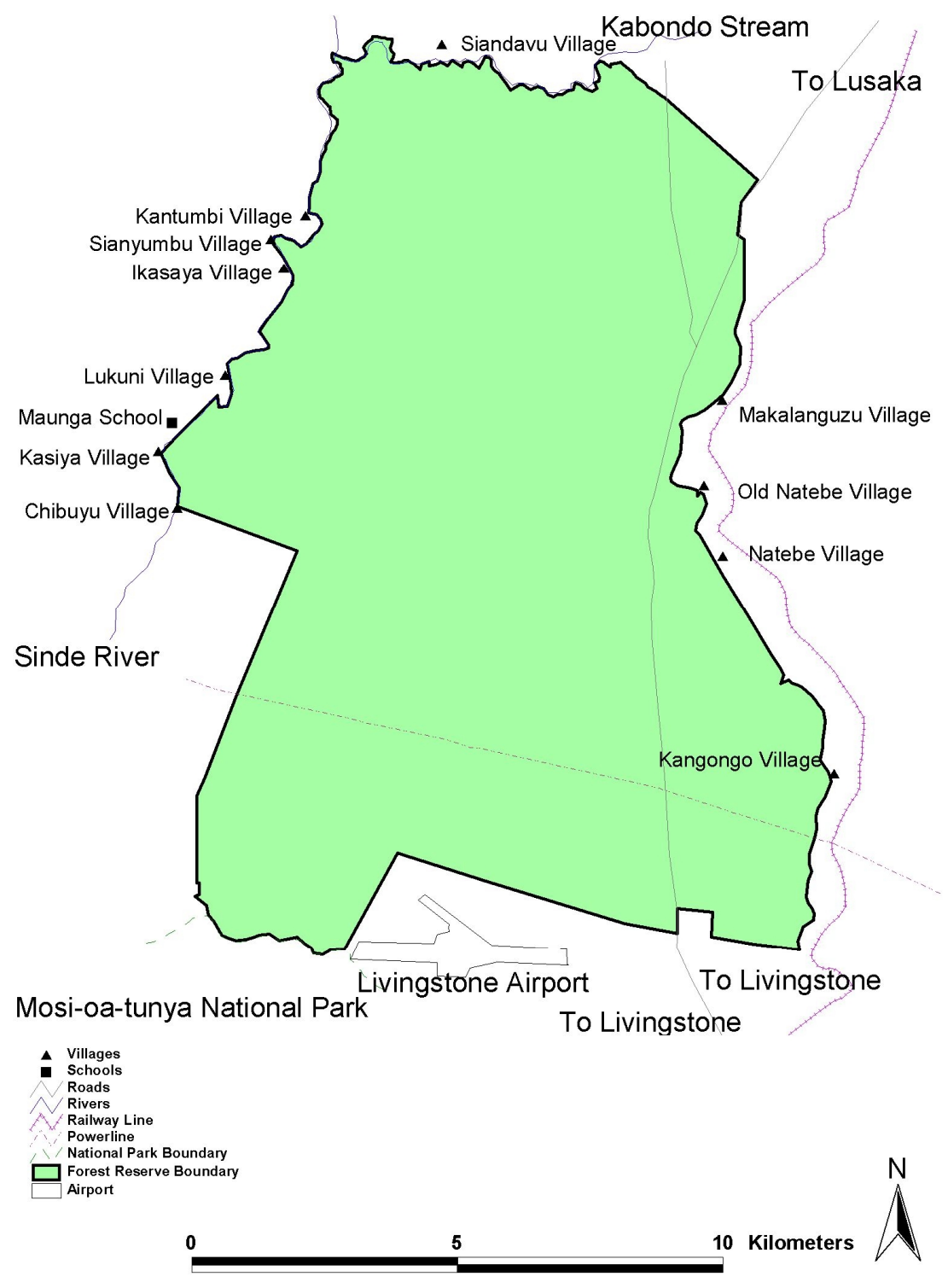

Figure 1: Dambwa joint forest management area in south-western Zambia

The study site at Dambwa Forest Reserve located in Livingstone District in the Southern

Province of Zambia (Figure 1) was one of the seven JFM pilot areas under the Provincial 
Forestry Action Programme (FD, 2003; PFAP, 2004). The forest reserve has an area of 10, 690 hectares and it is located between latitude $17^{\circ}$ and $18^{\circ}$ South and longitude $25^{\circ}$ and $26^{\circ}$ East, with an altitude of $1,000 \mathrm{~m}$ above sea level (FD, 2003). The area was set aside and gazetted as a protected forest area (Forest Reserve No. 22) in 1976 for the purpose of supplying timber, fuelwood and other forest products to the community in Livingstone. The JFM partnership was established in 2002 based on joint managements and sharing of the benefits derived from the forest reserve (FD, 2003; PFAP, 2005).

\section{Methods}

\section{Household survey}

A household questionnaire survey was the main tool used in the study. There were a total of 447 households in 11 villages surrounding Dambwa Forest Reserves. Based on this demographic data for the area, a sampling intensity of $25 \%$ was randomly selected to ensure that the households selected were a true representation of the population (Hetherington 1975; Turyahabwe 2006). Homestead in villages were scattered but grouped according to families. Sampling was based on sample frame showing names and respective numbers of each village and household. In order to choose the sample of households, each household was assigned a number and interviews were conducted with households whose numbers were selected (Babbie,2004). Both qualitative and quantitative methods of data collection were used in the study. A combination of techniques (a household questionnaire, discussions with focus groups and interviews with key informants) were used in data collection. The use of different techniques helped to triangulate the information generated (Bless and Higson-Smith, 2000). 
Data collection was done in two phases. The first phase involved the household survey with the use of a questionnaire. The second phase involved discussions with the focus groups such as the Forest Management Committee (FMC) and interviews with selected members of staff of Forest Department. A total of 7 Forest Management Committee members were selected from the respective Village Resource Management Committees. Thus 7 out of 11 villages were represented. The discussions were conducted in a semi-structured manner to enhance discussion among focus group participants, and also to allow the researcher to ask questions to several people at the same time.

\section{Forest regeneration}

The five commercially valuable timber species were selected for study to determine their regeneration dynamics namely; Baikaiea plurijuga, Pterocarpus angolensis, Afzelia quanzensis, Guibourtia coleosperma and Colophospermum mopane in Dambwa Forest Reserve. The cluster and plot locations were systematically established along transects of $150 \mathrm{~m}$. The main plot was $20 \mathrm{~m}$ in radius while the sub-plot was of $5 \mathrm{~m}$ radius. The use of the larger sample plot and a smaller subsample plot in data collection is an adoption from other studies in Southern African savannas (see Geldenhuys, 2000, Shea et al., 1993). In the main plot, all the woody plants of $>$ $2 \mathrm{~cm}$ diameter at breast height $(\mathrm{DBH})$ were identified and measured and recorded. The $5 \mathrm{~m}$ radius subplots were used to assess the presence of saplings, seedlings, sprouts and woody plants of $<$ $2 \mathrm{~cm} \mathrm{DBH}$. The trees and shrubs of this category were counted, identified and recorded. Land use pattern and ecological condition of the forest reserve were noted during the study of regeneration. A total of 25 plots were established for the study. This number was considered 
sufficient for collecting data that could be inferred upon to describe this woodland type considering that the vegetation type is not of high tree species variation and abundance.

\section{Data processing and analyses}

Table 1: Species names with their corresponding code names for figure 4

\begin{tabular}{|l|l|}
\hline Species Latin name & Code \\
\hline Afrelia quanzensis & AfzQua \\
\hline Albizia antunesiana & AlbAnt \\
\hline Annona senegalensis & AnnSen \\
\hline Baikiaea plurijuga & BaiPlu \\
\hline Baphia massaiensis & BapMass \\
\hline Baubinia petersiana & BauPet \\
\hline Boscia angustifolia & BosAng \\
\hline Brachystegia spiciformis & BraSpi \\
\hline Burkea africana & BurAfr \\
\hline Canthium glaucum sub grangula & CanGra \\
\hline Colophospermum mopane & ColMop \\
\hline Combretum imberbe & ComImb \\
\hline Combretum molle & ComMol \\
\hline Combretum zeyheri & ComZey \\
\hline Dichrostachys cinerea & DicCin \\
\hline Diospyros batocana & DioBat \\
\hline Diplorbyncus condylocarpon & DipCon \\
\hline Friesodielsia obovata & FriObo \\
\hline Guibourtia coleosperma & GuiCol \\
\hline Lannea stublmannii & LanStu \\
\hline Ochna pulcbra & OchPul \\
\hline Pseudolacnostylis maprouneifolia & PseMap \\
\hline Pterocarpus angolensis & PteAng \\
\hline Strychnos cocculoides & StrCoc \\
\hline Strychnos spinosa & StrSpi \\
\hline Terminalia sericea & TerSer \\
\hline Xylopia rubenscens & XylRub \\
\hline Others species & Others \\
\hline & \\
\hline
\end{tabular}

The data were coded in an appropriate format for entry into the computer for processing.

Descriptive statistical analyses and chi-square tests (Clewer \& Scarisbrick, 2006) were conducted to determine the levels of significance between different social status groups on their 
perception of JFM activities and benefits of JFM. Two categories of vegetation data sets were analyzed in the study namely stems of $\mathrm{DBH}>2 \mathrm{~cm}$ and those stems with $\mathrm{DBH} \leq 2 \mathrm{~cm}$ to develop size class profiles at both stand and population levels using Microsoft Excel 2003. Those with $\mathrm{DBH} \leq 2 \mathrm{~cm}$ were considered regeneration and data were collected in the $5 \mathrm{~m}$ radius circular sample plots. In order to provide for enough space on the figures, the species names were abbreviated in a standardized manner (see Table1)

\section{Results}

\section{Participation in JFM programme}

Generally, more people (68\%) participated in joint forestry management meetings than in the other forestry activities. In addition, the size of the household significantly influenced the involvement of community members in JFM activities $(p=0.03)$ with the most participation

Table 2 Participation in Joint Forest Management Activities by Social Status in Dambwa Forest Reserve $(\mathrm{N}=55)$

\begin{tabular}{llllll}
\hline JFM activities & \multicolumn{4}{c}{ Response by social status (\%) } & P value \\
\cline { 2 - 5 } & $\begin{array}{l}\text { Forest } \\
\text { Committee } \\
\text { Members }\end{array}$ & $\begin{array}{l}\text { Traditional } \\
\text { Leaders }\end{array}$ & $\begin{array}{l}\text { Forest User } \\
\text { Group } \\
\text { Members }\end{array}$ & $\begin{array}{l}\text { General } \\
\text { Community } \\
\text { Members }\end{array}$ & \\
\hline $\begin{array}{l}\text { Forest patrols } \\
\text { Boundary }\end{array}$ & 57 & 22 & 17 & 23 & 0.03 \\
$\begin{array}{l}\text { maintenance } \\
\begin{array}{l}\text { Prescribed } \\
\text { early burning }\end{array}\end{array}$ & 61 & 33 & 33 & 20 & 0.01 \\
\hline
\end{tabular}

being from households containing more than 7 occupants. The results also showed that the social status of the local community members played a significant role in their participation in JFM activities $(p<0.05)$. The study showed that the forest committee member group was 
significantly more involved (57-61\%) in forestry activities than any other group (Table 2). The social status significantly influenced the participation of individuals in forestry activities namely: forestry patrols $(p=0.03)$, boundary maintenance $(p=0.01)$ and prescribed burning $(p=0.03)$.

\section{Community benefits arising from JFM}

The study showed that forest user groups (71\%) followed by forest committee members $(50 \%)$ felt that there were benefits following the introduction of JFM. On the other hand, most community members (73\%) followed by traditional leaders $(63 \%)$ reported that there were no benefits from JFM programme in Dambwa (Table 3). In fact, the majority of the respondents (79\%) perceived the Forestry Department to be the major beneficiary under JFM, while $10 \%$ perceived the members of the forest management committee to be the major beneficiaries.

Table 3: Perception of Joint Forest Management Benefits (\%) Based on Social Status in Dambwa Forest Reserve $(\mathrm{N}=88)$

\begin{tabular}{lcccc}
\hline Benefits & \multicolumn{4}{c}{ Response in social position (\%) } \\
\hline Lraditional & $\begin{array}{l}\text { Forest } \\
\text { Committee } \\
\text { Members }\end{array}$ & $\begin{array}{l}\text { Forest User } \\
\text { Group } \\
\text { Members }\end{array}$ & $\begin{array}{l}\text { General } \\
\text { Community } \\
\text { Members }\end{array}$ \\
\hline $\begin{array}{l}\text { New skills } \\
\begin{array}{l}\text { Forest } \\
\text { resources }\end{array}\end{array}$ & 0 & 50 & 71 & 20 \\
$\begin{array}{l}\text { School } \\
\text { expansion }\end{array}$ & 13 & 14 & 0 & 8 \\
No benefits & 63 & 0 & 0 & 0 \\
\hline
\end{tabular}

\section{Perceived improvements of households and forest conditions}

The community felt that there was no significant improvement in the general household socioeconomic condition in the study area as a result of introducing JFM with more respondents (68\%) feeling that household conditions had remained the same following the introduction of 
JFM programme in the area. However, up to $51 \%$ of the respondents perceived that the illegal forestry activities had declined following the introduction of JFM. Additionally, more than a half of the local people interviewed (67\%), irrespective of the age, perceived the condition of Dambwa Forest Reserve had improved following the introduction of JFM (Table 4).

Table4: Perception of Local People about Forest Regeneration due to introduction of Joint Forest Management in Dambwa Forest Reserve by Age ( $N=86)$

\begin{tabular}{|l|l|l|l|l|l|}
\hline \multirow{2}{*}{ Age class } & \multicolumn{5}{|c|}{ Perception of regeneration by age groups } \\
\cline { 2 - 6 } & Observations & \multicolumn{1}{|c|}{ Worse } & \multicolumn{1}{c|}{ Same } & Improved & Unknown \\
\hline$\leq \mathbf{2 0}$ & 2 & 0 & 0 & $50 \%$ & $50 \%$ \\
\hline $\mathbf{2 1 - 3 5}$ & 26 & $27 \%$ & $15 \%$ & $58 \%$ & 0 \\
\hline $\mathbf{3 6 - 5 0}$ & 28 & $14 \%$ & $11 \%$ & $71 \%$ & $4 \%$ \\
\hline $\mathbf{5 1 - 6 5}$ & 19 & $16 \%$ & $11 \%$ & $68 \%$ & $5 \%$ \\
\hline $\mathbf{2 6 6}$ & 11 & $27 \%$ & $9 \%$ & $64 \%$ & 0 \\
\hline
\end{tabular}

\section{Forest ecological condition}

Stocking at stand and individual level

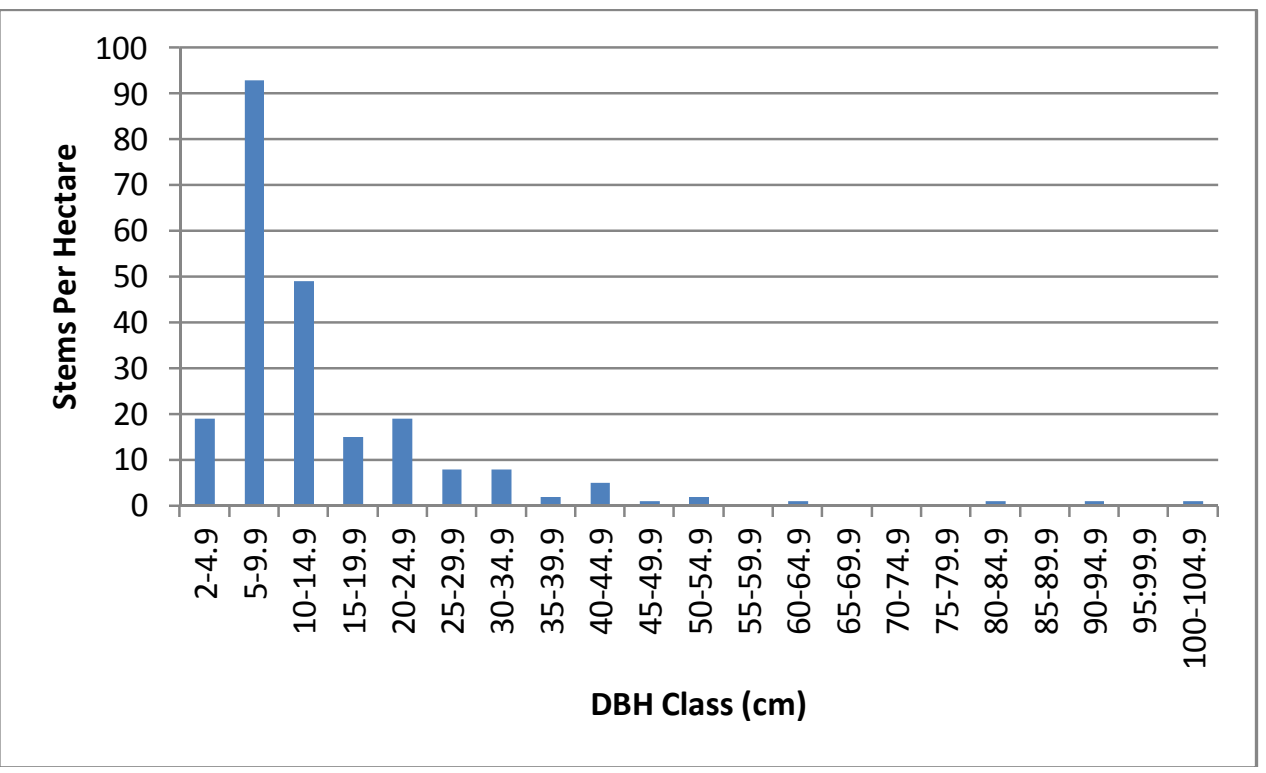

Figure 2: Forest Stocking and DBH Distribution in Dambwa Forest Reserve 
Stand level assessment indicated a stocking rate of 219 stems per hectare (SPH) of different tree species for the class $>2 \mathrm{~cm}$ DBH of which $90 \%$ was $<30 \mathrm{~cm}$ in DBH (Figure 2). The graph indicates an increase in stocking from 2.0-4.9 $\mathrm{cm}$ class to $5.9-9.9 \mathrm{~cm}$ class which is followed by a sharp drop thereafter. The classes that follow are characterized by fluctuation in stocking but with a marked drop in stems per hectare (SPH) with increasing diameter class.

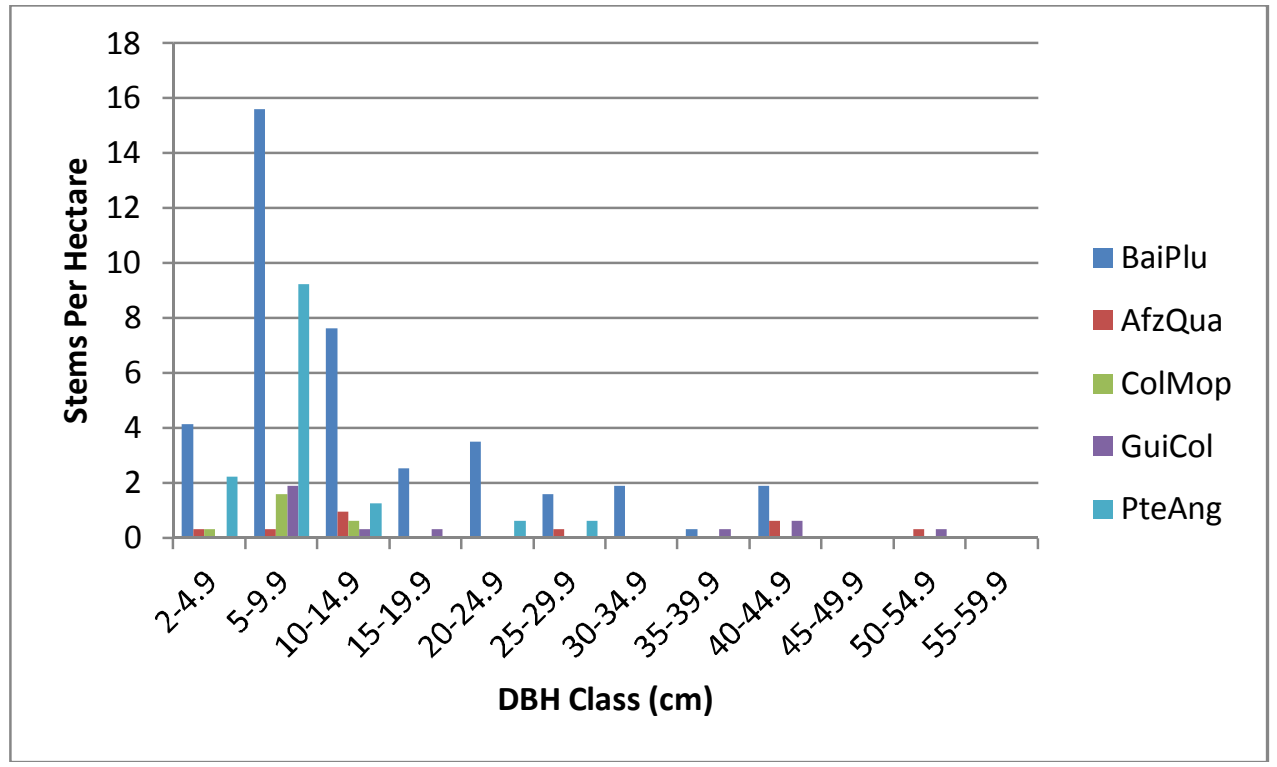

Figure 3: Stocking and DBH Distribution of Selected Valuable Tree Species

The stocking of individual population levels for the most valuable tree species varied from species to species namely: Baikiaea plurijuga (39 SPH), Pterocarpus angolensis (14 SPH), Guibourtia coleosperma (5 SPH), Afzelia quanzensis (3 SPH) and Colophospermum mopane (3 $\mathrm{SPH})$. In terms of size class distribution, the results showed that up to $89 \%$ of the selected valuable species stocking rate were less than $30 \mathrm{~cm}$ in DBH. Pterocarpus angolensis and Colophospermum mopane had 100\% of stems below $30 \mathrm{~cm}$ DBH, followed by Baikiaea plurijuga (90\%), Afzelia quanzensis (67\%), and Guibourtia coleosperma (57\%) (Figure 3). Each 
of these species exhibited a reverse $\mathrm{J}$ shaped size class profile with the lower classes having more stems than the upper classes.

Natural regeneration of Dambwa Forest Reserve

The results for forest regeneration assessment showed almost 10,000 saplings or seedlings growing per hectare. The most predominant species were Diplorhynchus condylocarpon $(2,007$ $\mathrm{SPH})$ and Bauhinia petersiana (1,986 SPH). The other tree species observed included Ochna pulchra (764 SPH), Baphia massaiensis (571 SPH) and Pseudolachnostylis maprouneifolia (230 SPH) (Figure 4). In the natural regeneration of the valuable species, Pterocarpus angolensis had $118 \mathrm{SPH}$, Baikaiea plurijuga $72 \mathrm{SPH}$ and Colophospermum mopane $67 \mathrm{SPH}$ ) while there was no regeneration observed in Afzelia quanzensis and Guibourtia coleosperma (Figure 4).

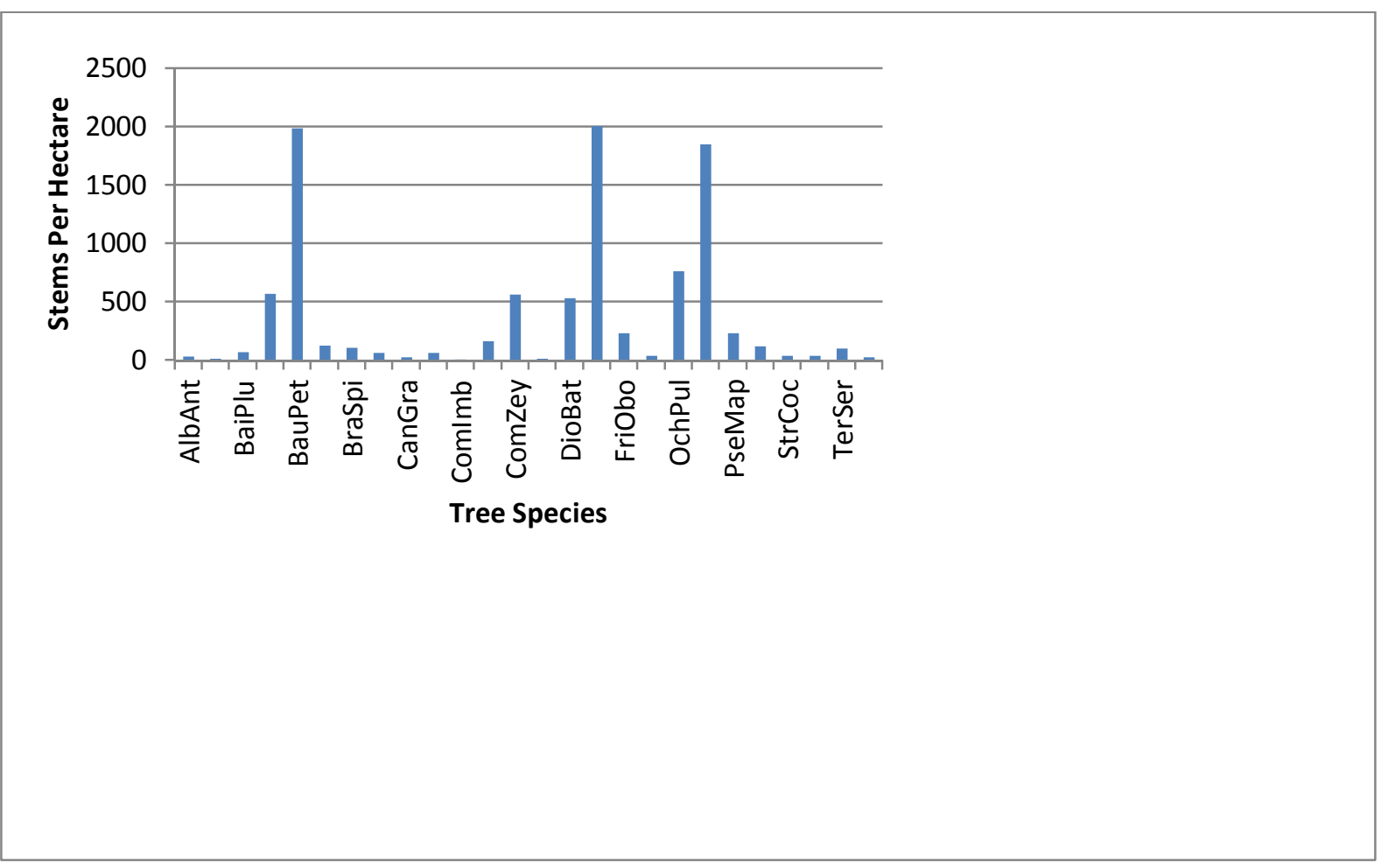

Figure 4: Natural Regeneration in Dambwa Forest Reserve 


\section{Discussions}

\section{Factors affecting community participation in JFM}

Most community members in the study area participated in JFM activities, especially meetings. It is most probable most people initially attended hoping for material gains such as allowances or food. Others may have attended meetings in order to have access to benefits that may accrue to the community in future (see Behera and Engel 2006). Holmes-Watts and Watts (2008) stated in their assessment of participatory natural resource management in Southern Cape forests in South Africa that organising meetings appears to be the only activity that forestry officials seem to understand well when implementing participatory forest, although these meetings often turn out to be empty talk shows, without yielding local benefits. However, attendance of meetings dwindles over time due to lack of tangible benefits. In addition, meetings were considered to be less strenuous than physical activities such as patrols and forest boundary maintenance.

Other factors that affect participation in JFM activities in the study area include household demographic statistics: such as household size and social status. The results suggest that members of the local management committees (FMC and VRMCs) participated more (numerically) in JFM activities than other stakeholders. The higher involvement of committee members in JFM activities could be attributed to their commitment to the JFM project and to the fulfilment of their obligations as elected members of the management committees. Additionally, local management committee members had other privileges such as project bicycles, allowances during off-site meetings, authority and prestige. These privileges seemed to have compelled them to be more involved in JFM activities in order to retain their elected positions and continue enjoying these privileges. It is also possible that those who were elected in these positions would 
have been hardworking committed members of the society. However, it is equally important when such programmes are formulated that necessary precautions are taken to avoid electing only the more vociferous, visible, educated or wealthy members of local communities and excluding the poor and powerless who lack these leadership qualities.

Household sizes also had an effect on the local people's participation in JFM activities. The study showed that households with less than 7 members participated less compared to those with more than 7 members. This is probably because larger households are able to allocate labour and time among the occupants and participate in JFM activities to diversify their livelihoods strategies. Behera and Engel (2006) observed that smaller household sizes have difficulties in finding time for JFM activities because of family responsibilities such as domestic or other chores.

\section{Sharing of costs and benefits under JFM}

The majority of the people interviewed indicated that there were no monetary benefits accruing to them as a result of their involvement in JFM programme. This could be attributed to the fact that many people in the area do not obtain as many tangible economic benefits from JFM as they would like. There is thus a high expectation on JFM, as it is often the case in a rural poor setting. It is also probable that communities considered benefits in monetary terms only such as through forest user groups but not the benefits that they derived from non- timber forest products. While this study did not establish the values of the NTFPs in Dambwa Forest Reserve, there were examples of NTFPs derived from the forest including firewood, fruits such as Schinziophyton rautanenii (Mungongo) which was used for oil extraction. Future studies should consider NTFPs as part of the benefits. Notwithstanding, Neumann and Hirsch (2000) have highlighted 
that research into the economic significance of NTFPs has not been particularly quantitative, complete or definitive. They argued that most studies describe, explicitly or implicitly, a favourable picture for the marketing of NTFP products. Thus in this case NTFPs benefits could have been equated to value in exchange, value in use, and indeed in future even payment for ecosystem services.

Jumbe and Angelsen (2007) have argued that distribution of benefits between the state and local communities is a critical factor in JFM successes. Local communities would normally reject projects where opportunity costs of their participation are higher than the benefits (Bwalya 2004; Behera and Engel 2006). This is true with the local communities around the Dambwa JFM area who are seemingly discouraged from active participation in JFM activities due to lack of equitable sharing of economic benefits. Others felt that their participation in JFM activities was being used as a form of cheap source of labor by the Forestry Department. It may be possible that from the communities' perspective, it was expected that JFM activities would result in social upliftment through the utilization of the previously denied forest resources and benefits accruing from their management efforts. On the other hand, the vegetation assessment showed that the forest is still not ready for exploitation of the valuable species as most of the forest is still in the low diameter class. It is therefore important that there should be good communication through the VRMCs and/or FMC that informs communities about the state of the resource and the implications for resource use. This is because local people forego some of their time and activities to participate in JFM activities, with the expectation that they would benefit in the process of their participation since participation of local community in JFM is considered as an 
investment from which they expect a reward (Coralie and White 1994; Dolisca et al. 2006, Jumbe and Angelsen 2007).

\section{Perceived improvements of household livelihoods}

While the communities felt that there was no apparent improvement in their livelihood as a result of JFM, our questionnaire may not have captured what other studies have shown: the important role forests play in supplementing the household livelihoods. Forest products are often important in filling seasonal or cash flow gaps and help local communities to cope in difficult times. Most of the NTFPs collected from Forest Reserve, such as mushroom, fruits, tubers and wild vegetables, are seasonal and are available during the months of food shortages. The use of woodland as a source of the above products as well as fuelwood and charcoal has been reported by many researchers in other parts of the Miombo ecozone and the savanna woodlands (Syampungani et al., 2011; Chirwa et al., 2008; Shackleton et al., 1998; Chidumayo and Siwela 1988; Grundy et al., 1993). Hence, although agriculture was reported as the main livelihood activity of local people around Dambwa Forest Reserve, the forest reserve also plays a significant in the local people's livelihoods.

\section{Forest condition}

\section{Diameter Distribution}

The results of the study indicated that there were few bigger trees compared to smaller ones for the species that were harvested (see Figures 2 and 3). The absence of stems in larger size classes for timber species may be attributed to selective harvesting of such species when these species were prized as important commercial timber species. This is an indication of the impact of species exploitation (Peter, 2005). Many studies conducted in the other parts of the ecoregion 
(see for example Luoga et al., 2002; Syampungani, 2008) have also shown low levels of mature timber species such as Albizia antunesiana, Pterocarpus angolensis and Brachystegia floribunda. The sparse distribution of larger stems has an impact on their regeneration potential (Syampungani, 2008)

The results also showed that the harvested timber species exhibited a reverse $\mathrm{J}$ shaped size class profile. Size class profiles for species Baikiaea plurijuga, Pterocarpus angolensis, Guibourtia coleosperma, Afzelia quanzensis and Colophospermum mopane which were under timber harvesting indicate that timber harvesting has an impact on the regeneration of these species; implying that these species require larger gaps to regenerate and become established. In addition, most $(89 \%)$ of the stems for the selected commercial species were less than $30 \mathrm{~cm} \mathrm{DBH}$; rendering them unsuitable for harvesting. While there were high regeneration levels $(10,000$ saplings per ha) among the selected commercial trees, only Pterocarpus angolensis, Baikiaea plurijuga and Colophospermum mopane had some form of natural regeneration.

\section{Forest Regeneration}

Joint management of the forest reserve might have been the most likely contributing factor that led to increased number of observed saplings, particularly for Pterocarpus angolensis and Baikiaea plurijuga in the forest. It is therefore possible with proper forest protection and management to have sufficient natural regeneration in forest reserves as result of JFM. Nonoccurrence of Afzelia quanzensis and Guibourtia coleosperma saplings can be attributed to low stocking per hectare of these tree species. It is also possible that the few or the absence of larger trees of more than $30 \mathrm{~cm}$ DBH per hectare that were left standing in the Dambwa Forest Reserve 
for production of seeds in order to enhance regeneration may have had a negative effect on forest regeneration.

Evidence of large number of saplings per hectare in Dambwa Forest Reserve suggests that the forest protection and management activities conducted by the Forestry Department in collaboration with the local communities were effective in promoting forest regeneration. This would imply that even with low levels of participation by communities in strenuous activities, there was still a positive impact on the forest condition. Higher presence of seedlings or saplings is associated with reduced competition for light, nutrients and moisture. Therefore, distribution of smallest diameter trees in the forest reserve suggests that with proper management, the forest may have the potential to regenerate, permitting trees to grow into larger diameter classes. However, in areas where other tree species remain in the canopy layer, saplings under the canopy may remain suppressed or eventually die (Werren et al., 1995). The forest protection and management activities in this study included: forest patrols, early burning and boundary clearing and maintenance (Phiri, 2009). The study has, therefore, shown that natural regeneration of tree species in the Reserve could be enhanced with effective forest protection and management through participation of local communities under JFM. Improved regeneration after protection from continuous illegal harvesting, overgrazing and uncontrolled fires (Damodaran and Engel, 2003) has also been reported in West Bengal where the Forestry Department organised the local communities into Forest Protection Committees to protect forests from illegal harvesting, overgrazing, fires and encroachment. 
The majority of the respondents had the perception that the state of the Dambwa Forest Reserve had improved after the introduction of JFM. The improvement was attributed to the involvement of the local community in forest protection and management, albeit with low participation. The collaborative management and protection of the forest reserve resulted in reduced late wild fires, elimination of encroachment, and control of illegal and unsustainable harvesting of major forest products, which subsequently enhanced natural regeneration of the forest. While there is an appreciation of the improved forest condition, there is need to establish the reasons why communities felt that they had not benefited from JFM. This may be through a more detailed assessment of the so called not valuable forest products from the forest reserve.

\section{Conclusion}

Although JFM is viewed as an appropriate strategy towards supporting sustainable forest management and rural livelihoods in many countries, the community in the study area seemed to have associated benefits with economic (monetary) gains. However, the results showed that JFM seems to have improved the condition of forest through enhanced natural regeneration. It can therefore be concluded that while the promotion of community involvement in forest protection and management contributes to regeneration of forest tree species, the communities did not perceive JFM as having improved their livelihood. It is recommended that future assessments should include more detailed socio-economic analysis that also recognizes the important role of the so called non valuable forest products from the forest reserve: the NTFPs. In addition, future JFM implementation should clearly outline to local communities the mechanisms of benefit sharing. 


\section{Acknowledgement}

The authors would like to thank Ministry of Foreign Affairs of Finland through the Provincial Forestry Action Programme (PFAP II) and the Forest Department of Zambia for funding the study.

\section{References}

Babbie ER. 2004. The Practice of Social Research. 10th Edition. Thomson, Wadsworth.

Belmont, California.

Behera B, Engel S. 2006. Who Forms Local Institutions? Levels of Household Participation in India's Joint Forest Management Program, ZEF -Discussion Papers on Development Policy No. 103. Bonn: Center for Development Research.

Bless C, Higson-Smith C. 2000. Fundamentals of Social Research Methods.An African Perspective. Third Edition. Juta Publication.

Blomley T, Ramadhani H. 2006. Going to Scale with Participatory Forest Management: Early Lessons from Tanzania. International Review Volume 8 (1): 93-100.

Bwalya SM. 2004. Rural Livelihoods and Collective Action in Joint Forest Management in Zambia. http://www.saga.cornell.edu/images/cau-bwalya.pdf (Accessed on 13February 2007). 
Chidumayo EN, Siwela AA. 1988. Utilisation, Abundance and Conservation of Indigenous Fruits in Zambia. Paper presented at the ABN workshop on Utilization and Exploitation of Indigenous and often Neglected Plants and Fruits of Eastern and Southern Africa, 21-27 August, 1988, Zomba, Malawi.

Chirwa PW, Syampungani S, Geledenhuys C. 2008. The ecology and management of the miombo eco-region for sustainable livelihoods in southern Africa: The case for non timber forest products. Southern Forests 70(3): 237-245.

Clewer AG, Scarisbrick DH. 2006. Practical Statistics and Experimental Design for Plant and Crop Science. New York: John Wiley and Sons.

Coralie B, White LG. 1994. Managing Rural Development with Small Farmer Participation. Connecticut: Kumarian Press Inc.

Damodaran A, Engel S. 2003. Joint Forest Management in India: Assessment of Performance and Evaluation of Impacts. ZEF-Discussion Papers on Development Policy 77.

Dolisca F, Carter DR, McDaniel JM, Shannon DA, Jolly CM. 2006. Factors Influencing Farmer's Participation in Forestry Management Programs: A Case Study from Haiti. Forest Ecology and Management 236(2\&3):324-331. 
Forestry Department (FD). 2003. Final Draft Joint Forest Management Plan for Dambwa Local Forest. Lusaka: Forestry Department.

Geldenhuys CJ. 2000. The need for recruitment, growth and mortality in the indigenous forests: Examples from Northern Province. In: Seydack AHW, Vermeulen WJ and Vermeulen C (eds.), Towards sustainable management based on scientific understanding of natural forests and woodlands. Proceeding: Natural Forests and Woodland Symposium II, Knysna, South Africa, 59 September, pp.17-28.

Government of the Republic of Zambia (GRZ). 1998. National Forestry Policy. Lusaka: Ministry of Environment and Natural Resources.

Government of the Republic of Zambia (GRZ). 1999. Forests Act, Government Printers, Lusaka, Zambia.

Grundy IM, Campbell B, Balebereho S, Cunliffe R, Tafangenyasha C, Ferguson R, Parry D. 1993. Availability and Use of Trees in Mutanda Resettlement Area, Zimbabwe. Forest Ecology and Management 56: 243-266.

Hetherington JC. 1975. Samples? What shape? How large? How many? Scottish Forestry 29: 260-267. 
Holmes-Watts TN, Watts S. 2008. Legal frameworks for and the practice of participatory natural resources management in South Africa. Journal of Forest Policy and Economics. doi:10.1016/j.forpol.2008.02.005.

Jumbe CBL, Angelsen A. 2007. Forest Dependence and Participation in CPR Management: Empirical Evidence from Forest Co-management in Malawi. Ecological Economics 62: 661-667.

Lise W. 2000. Factors Influencing People's Participation in Forest Management in India. Ecological Economics 34: 379-392.

Luoga EJ, Witkowski ETF, Balkwill K. 2002. Harvested and Standing Wood Stocks in Protected and Communal Woodlands of Eastern Tanzania. Forest Ecology and Management, 164, 15-30.

Murali KS, Rao RJ, Sudha P, Sangeetha G, Murthy IK, Ravindranath NH. 2003. Evaluation studies of joint forest management in India: Social and Institution implications. International Journal of Environment and Sustainable Development 2(1): 19-35.

Neumann RP, Hirsch E. 2000. Commercialisation of non-timber forest products: review and analysis of research. Center for International Forestry Research, Bogor

Obua J, Banana AY, Turyahabwe N. 1998. Attitude of Local Communities Towards Forest Management Practices in Uganda: The Case of Budongo Forest Reserve. Commonwealth Forestry Review 77: 113-118. 
Ostrom E. 1999. Self governance and forest resources. Occasional Paper No. 20. Bogor: Centre for International Forestry Research.

Peter MC. 2005. Sustainable Harvesting of Non-timber plant resources in tropical moist forest: An ecological primer. http//www.worldwildlife.org. (Accessed on 12/11/2005).

PFAP (Provincial Forestry Action Programme). 2005. Lessons learnt from joint forest management in Zambia. The Experience of Provincial Forestry Action Programme (PFAP II). Programme Coordination Unit. Lusaka: Forestry Department.

Phiri M. 2009. Evaluation of the Performance of Joint Forest Management (JFM) Programme: Case of Dambwa Forest Reserve in Livingstone District, Zambia Unpublished. MSc Thesis. University of Stellenbosch, South Africa.

Raphael T, Swai G. 2009. The impact of participatory forest management and local people's perceptions on its implementation at village level in Mufindi District, Southern Tanzania highlands. In Nshubemuki L, Chamshama SAO, Balama C (eds.), Participatory Forest Management for Improved Forest Quality, Livelihoods and Governance. Proceedings of the First Participatory Forest Management Research Workshop. Morogoro: Tanzania Forestry Research Institute. pp.133-146. 
Sethi P, Khan H. 2001. Structuring Financial Empowerment for Localized Development within Joint Forest Management: Examples from Madhya Pradesh, India. Sustainable Development 9: $87-102$

Shackleton S, Dzerefos E, Shackleton CM, Mathabela FR. 1998. Use and trading of wild herbs in the central lowveld savannah region, South Africa. Economic Botany 52(3): 251-259.

Shea RW, Kauffman JB and Shea BW 1993. Fuel biomass and combustion factors associated with fires in Savanna ecosystems of South Africa and Zambia: Report submitted to the USDA Forest Service. Missoula: Intermountain Research Station.

Syampungani S, Geldenhuys C, Chirwa PW 2011. Miombo Woodland Utilization and Management, and Impact Perception among Stakeholders in Zambia: A Call for Policy Change in Southern Africa. Journal of Natural Resources Policy Research 3(2): 163-181.

Syampungani S. 2008. Vegetation change analysis and ecological recovery of the Copperbelt miombo woodlands of Zambia. PhD Thesis, University of Stellenbosch, Stellenbosch.

Turyahabwe N. 2006. Local Capacity to Manage Forestry Resources Under a Decentralised System of Governance: The Case of Uganda. PhD Thesis, University of Stellenbosch, South Africa. 
United Nations Conference on Environment and Development (UNCED). 2008. Encyclopædia Britannica. 2008. Encyclopædia Britannica Online.

http://www.britannica.com/EBchecked/topic/616390/United-Nations- Conference-onEnvironment-and-Development. (Accessed on 1 December 2008)

Vandergeest P. 1996. Property Rights in Protected Areas: Obstacles to Community Involvement as a Solution in Thailand. Environmental Conservation 23: 259-268.

Werren M, Lowore J, Abbot P, Siddle B, Hardcastle P. 1995. Management of miombo by local communities. Zomba: University of Aberdeen and Forestry Research Institute of Malawi.

Wily LA. 2002. Participatory Forestry Management in Africa. An overview of Progress and Issues. Community-Based Natural Resource Management Net.

World Bank. 2004. Sustaining Forests, A Development Strategy. Washington D.C: World Bank Ltd.

Zambia Forestry Action Programme (ZFAP). 1998. Zambia Forestry Action Plan. Lusaka: Ministry of Environment and Natural Resources. 